\title{
Analisis Faktor Terhadap Komoditas Pangan di Kabupaten Gresik
}

\author{
Anik Rufaidah \\ Program Studi Teknik Industri, Sekolah Tinggi Teknik Qomaruddin Gresik \\ Anikrufaidah.99@gmail.com
}

\begin{abstract}
ABSTRAK
Komoditas pangan merupakan hal yang penting untuk memenuhi kebutuhan manusia, denganterpenuinya komoditas pangan maka kesejahteraan manusia dapat terpenuhi. Untuk mengingkatkan ketahanan pangan yang ada di lingkungan kabupaten Gresik, sehingga perlu diadakan penelitian tentang semua komoditas pangan yang dikonsumsi oleh masyarakat pada tahun 2016 dan 2017. Hal ini perlu dilakukan penelitian tentang faktor-faktor apa saja yang berpengaruh terhadap komoditas pangan di kabupaten Gesik, sehingga dapat meningkatkan kesejahteraan masyarakat. Yang mana hasil analisis faktor pada tahun 2016 didapat faktor 1 diantaranya tanaman jagung $(X 2)$, tanaman umbi(x4), tanaman pangan(X5) dan tanaman buah-buahan(X6). Dan untuk variabel yang masuk dalam faktor 2 diantaranya yaitu tanaman padi(X1), tanaman kedelai(X3) dan tanaman sayur(X7). Sedangkan untuk analisis faktor pada tahun 2017 adalah faktor 1 yaitu tanaman jagung (X2), tanaman buah-buahan (X5) dan tanaman sayur-sayuran(X6). Sedangkan faktor 2 yaitu tanaman padi (X1) dan tanaman pangan (X4). Dan untuk yang masuk dalam faktor 3 diantaranya tanaman kedelai (X3) dan tanaman umbi (x4), untuk tanaman jagung, buah-buahan dan sayur.
\end{abstract}

Kata Kunci: Analisis Faktor, Komoditi.

\section{ABSTRACT}

Food commodities are important to supply human needs, with supplied by food commodities, human life can be prosperous. To improve the food durability in Gresik regency, it is necessary to research on all food commodities consumed by public in 2016 and 2017. This necessarily is to research on what factors affect of the food commodities in Gresik district, so it can improve people's welfare. Which result of factors analyzed in 2016, they used plant as variables for factor 1 were corn (X2), tuber (X4), food crop (X5) and fruit (X6). And for the variables included in factor 2 were rice $(X 1)$, soybean(X3) and vegetable (X7). Whereas in 2017 the plant as variable analyzed of factor 1 are corn (X2), fruit (X5) and vegetable (X6). And of factor 2 are rice (X1) and food corp (X4). And for those included of factor 3 are soybean (X3) and tuber (X4), for corn, fruits and vegetables.

Keyword: Factor Analyzed, commodities. 


\section{PENDAHULUAN}

Komoditas pangan merupakan semua hal yang dikonsumsi yang berasal dari tanah dengan batuan air yang digunakan oleh manusia untuk bahan makanan. Komoditas pangan merupakan hal yang penting untuk memenuhi kebutuhan manusia, dengan terpenuinya komoditas pangan maka kesejahteraan manusia dapat terpenuhi.

Dikabupaten Gresik yang merupakan daerah berkembang, mana kesejahteraan masyarakat sekitar yang mulai meningkat dengan tingkat kesejahteraan menengah keatas. Sebagai masyarakat pada umumnya yang diharapkan bagaimana harga komoditas pangan ini menjadi stabil dan harga-harga dapat terjangkau oleh masyarakat oleh masyarakat.

$$
\text { Untuk mengingkatkan }
$$

ketahanan pangan yang ada di lingkungan kabupaten Gresik, sehingga perlu diadakan penelitian tentang semua komoditas pangan yang dikonsumsi oleh masyarakat. Dari semua komoditas pangan yang dikonsumsi masyarakat Gresik, perlu mempengaruhi komoditas pangan apa saja yang mempengaruhi masyarakat di kabupaten gresik. Dengan adanya faktor-faktor yang mempengaruhi komoditas pangan di kabupaten Gresik, sehingga dapat dicari apa penyebabnya sehingga faktor tesebut sangat berpengaruh terhadap kehidupan yang ada di kabupaten Gresik.

Dengan dikatahuinya penyebab pengaruh dari faktor-faktor komoditas pangan yang ada dikabupaten Gresik pada tahun 2016 dan 2017. Sehingga diharapkan dapat dijadikan suatu kebijakan untuk memperbaikan kondisi yang ada di lingkungan masyarakat kabupaten Gresik tersebut. Dan dapat digunakan rekomendasi untuk kebijakan daerah kabupaten Gresik.

Untuk penelitian tersebut menyelesaikan permasalahan bagaimana faktor-faktor yang mempengaruhi komoditas pangan yang ada di kabupaten Gresik. Sehingga dari permasalahan tersebut dapat diperoleh tujuan yang jelas tentang apa saja factor yang berpengaruh tersebut, dengan menggunakan metode "analisis faktor". Dan masalah ini hanya kita batasi untuk kecamatan yang ada di kabupaten Gresik.

\section{ANALISIS KOMPONE UTAMA}

Analisis Komponen Utama (Principal Component Analysis) adalah analisis multivariate yang mentransformasi variabel-variabel asal yang saling berkorelasi menjadi variabel-variabel baru yang tidak saling berkorelasi dengan mereduksi sejumlah variabel tersebut sehingga mempunyai dimensi yang lebih kecil namun dapat menerangkan sebagian besar keragaman variable aslinya (Johnson dan Wichern, 2002).

Banyaknya komponen utama yang terbentuk sama dengan banyaknya variabel asli. Pereduksian (penyederhanaan) dimensi dilakukan dengan kriteria persentase keragaman data yang diterangkan oleh beberapa komponen utama pertama. Apabila beberapa komponen utama pertama telah menerangkan lebih dari $75 \%$ keragaman data asli, maka analisis cukup dilakukan sampai dengan komponen utama tersebut. Bila komponen utama diturunkan dari populasi multivariat normal dengan 
random vektor $\mathbf{X}=(X 1, X 2, \ldots, X p)$ dan vektor rata-rata $\mu=(\mu 1, \mu 2, \ldots, \mu p)$ dan matriks kovarians $\boldsymbol{\Sigma}$ dengan akar ciri (eigenvalue) yaitu $\lambda 1 \geq \lambda 2 \geq \cdots \geq \lambda p \geq 0$ didapat kombinasi linier komponen utama yaitu sebagai berikut.

$$
Y_{1}=e_{11}^{\prime} X_{1}+e_{21}^{\prime} X_{2}+\cdots+e_{p 1}^{\prime} X_{p}
$$

$$
Y_{2}=e_{12}^{\prime} X_{1}+e_{22}^{\prime} X_{2}+\cdots+e_{p 2}^{\prime} X_{p}
$$$$
Y_{p}=e_{1 p}^{\prime} X_{1}+e_{2 p}^{\prime} X_{2}+\cdots+
$$

$e_{p p}^{\prime} X_{p}$

Maka $\operatorname{Var}(Y i)=$ ei'Lei dan $\operatorname{Cov}(Y i, Y k)=e i$ 'Lei dimana $i, k=1,2, \ldots$ , p. Syarat untuk membentuk komponen utama yang merupakan kombinasi linear dari variabel $\mathbf{X}$ agar mempunyai varian maksimum adalah dengan memilih vektor ciri (eigen vector) yaitu $e=(e 1, e 2, \ldots, e p)$ sedemikian hingga $\operatorname{Var}(Y i)=e i^{\prime} \Sigma e i$ maksimum dan eiei $=1$.

- Komponen utama pertama adalah kombinasi linear $e 1^{\prime} X$ yang memaksimumkan $\operatorname{Var}(e 1 ' X)$ dengan syarat $e 1$ 'e1 $=1$.

- Komponen utama kedua adalah kombinasi linear $e 2 ' X$ yang memaksimumkan $\operatorname{Var}\left(e 2^{\prime} X\right)$ dengan syarat $e 2^{\prime} e 2$ $=1$.

- Komponen utama ke-i adalah kombinasi linear ei' $X$ yang memaksimumkan $\operatorname{Var}(e i X)$ dengan syarat ei'ek $=1$ dan $\operatorname{Cov}\left(e i^{\prime} e k\right)=0$ untuk $k<1$.

Antar komponen utama tersebut tidak berkorelasi dan mempunyai variasi yang sama dengan akar ciri dari $\boldsymbol{\Sigma}$. Akar ciri dari matriks ragam peragam $\boldsymbol{\Sigma}$ merupakan varian dari komponen utama $\mathbf{Y}$, sehingga matriks ragam peragam dari $\mathbf{Y}$ adalah:

$$
\boldsymbol{\Sigma}=\left[\begin{array}{ccc}
\lambda_{1} & \ldots & 0 \\
\ldots & \ldots & \ldots \\
0 & 0 & \lambda_{p}
\end{array}\right]
$$

Total keragaman variabel asal akan sama dengan total keragaman yang diterangkan oleh komponen utama yaitu:

$\sum_{j=1}^{p} \operatorname{var}\left(X_{1}\right)=\operatorname{tr}(\boldsymbol{\Sigma})=\lambda_{1}+\lambda_{2}+\cdots+$ $\lambda_{p}=\sum_{j=1}^{p} \operatorname{Var}\left(Y_{i}\right)$

Penyusutan dimensi dari variabel asal dilakukan dengan mengambil sejumlah kecil komponen yang mampu menerangkan bagian terbesar keragaman data. Apabila komponen utama yang diambil sebanyak $q$ komponen, dimana $q<p$, maka proporsi dari keragaman total yang dapat diterangkan oleh komponen utama ke- $i$ adalah:

$$
\frac{\lambda_{1}}{\lambda_{1}+\lambda_{2}+\cdots+\lambda_{p}} \quad \mathrm{t}=1,2, \ldots
$$

(3)

Penurunan komponen utama dari matriks korelasi dilakukan apabila data sudah terlebih dahulu ditransformasikan ke dalam bentuk baku Z. Transformasi ini dilakukan terhadap data yang satuan pengamatannya tidak sama. Bila variabel yang diamati ukurannya pada skala dengan perbedaan yang sangat lebar atau satuan ukurannya tidak sama, maka variabel tersebut perlu dibakukan (standardized).

Variabel baku (Z) didapat dari transformasi terhadap variabel asal dalam matriks berikut:

$$
Z=\left(V^{1 / 2}\right)^{-1}(X-\mu)
$$

$\mathbf{V} 1 / 2$ adalah matriks simpangan baku dengan unsur diagonal utama adalah (aii) 1/2 sedangkan unsur lainnya 
adalah nol. Nilai harapan $E(\mathbf{Z})=0$ dan keragamannya adalah:

$$
\operatorname{Cov}(\mathbf{Z})=\left(\mathbf{V}^{1 / 2}\right)^{-1} \boldsymbol{\Sigma}\left(\mathbf{V}^{1 / 2}\right)^{-1}=\rho
$$

Dengan demikian komponen utama dari $Z$ dapat ditentukan dari vektor ciri yang didapat melalui matriks korelasi variabel asal $\rho$. Untuk mencari akar ciri dan menentukan vektor pembobotnya sama seperti pada matriks $\boldsymbol{\Sigma}$. Sementara trace matriks korelasi $\rho$ akan sama dengan jumlah $p$ variabel yang dipakai. Pemilihan komponen utama yang digunakan didasarkan pada nilai akar cirinya, yaitu komponen utama akan digunakan jika akar cirinya lebih besar dari satu.

\section{ANALISIS FAKTOR}

Analisis faktor merupakan salah satu metode statistik multivariat yang mencoba menerangkan hubungan antara sejumlah variabelvariabel yang saling independen antara satu dengan yang lain sehingga bisa dibuat satu atau lebih kumpulan peubah yang lebih sedikit dari jumlah variabel awal. Analisis faktor digunakan untuk mereduksi data dan menginterpretasikannya sebagai suatu variabel baru yang berupa variabel bentukan. Analisis faktor juga digunakan untuk mengetahui faktorfaktor dominan dalam menjelaskan suatu masalah. Di dalam analisis varian, regresi berganda dan diskriminan, satu variabel disebut sebagai variabel tak bebas (dependent variable) atau kriterion dan variabel lainnya sebagai variabel bebas atau prediktor. Di dalam analisis faktor disebut teknik interdependensi (interdependence technique) di mana seluruh set hubungan yang independen diteliti (Supranto, 2010). $\mathrm{Di}$ dalam analisis faktor, variabel tidak dikelompokkan menjadi variabel bebas dan tidak bebas, sebaliknnya penggantinya seluruh set hubungan interdependen antar variabel diteliti. Analisis faktor dapat pula dipandang sebagai perluasan dari analisis komponen utama. Keduanya merupakan teknik analisis yang menjelaskan struktur hubungan diantara banyak variabel dalam sistem konkret.

Tujuan dari analisis faktor adalah untuk menggambarkan hubungan - hubungan kovarian antara beberapa variabel yang mendasari tetapi tidak teramati, kuantitas random yang disebut faktor (Johnson and Wichern, 2007).

Menurut Kachigan (1986), aplikasi penggunaan analisis faktor bertujuan untuk :

a. Identifikasi Faktor yang Mendasari Salah satu penggunaan yang paling penting dari analisis faktor adalah untuk mengidentifikasi faktor yang mendasari dari sekumpulan besar variabel. Dengan mengelompokkan sejumlah besar variabel ke dalam jumlah yang lebih kecil dari kumpulan yang homogen dan membuat variabel baru yang disebut faktor yang mewakili sekumpulan variabel tersebut dalam bentuk yang lebih sederhana, maka akan lebih mudah untuk diinterpretasikan.

b. Penyaringan Variabel (Screening of variables)

Penggunaan penting dari analisis faktor selanjutnya adalah penyaringan variabel untuk disertakan dalam penelitian statistik selanjutnya, 
seperti analisis regresi atau analisis diskriminan.

c. Meringkas Data (Summary of Data)
Penerapan analisis faktor selanjutnya adalah untuk mengekstrak sedikit atau banyak faktor sesuai yang diinginkan dari satu set variabel.

\section{d. Memilih Variabel (Sampling of} Variables)

Penggunaan teknik analisis
faktor selanjutnya adalah untuk memilih sekelompok kecil perwakilan variabel yang representatif, walaupun sebagian besar variabel berkorelasi, hal ini bertujuan untuk memecah berbagai masalah praktis.

\section{e. Pengelompokkan Objek (Clustering of Objects)}

Selain mengidentifikasi kesamaan antara variabel, analisis faktor dapat digunakan untuk mengelompokkan objek.. Dalam prosedur ini, sering disebut analisis faktor sebagai inverse, sebuah sampel individu diukur pada sejumlah variabel acak, dan dikelompokkan ke dalam kelompok yang homogen berdasarkan antar-korelasinya.

\section{MODEL ANALISIS FAKTOR}

Secara matematis, analisis faktor agak mirip dengan regresi linear berganda, yaitu bahwa setiap variabel dinyatakan sebagai suatu kombinasi linear dari faktor yang mendasari (underlying factors). Jumlah (amount) varian yang disumbangkan oleh suatu variabel dengan variabel lainnya yang tercakup dalam analisis disebut communality. Kovariasi antara variabel yang diuraikan, dinyatakan dalam suatu common factors yang sedikit jumlahnya ditambah dengan faktor yang unik untuk setiap variabel. Faktorfaktor ini tidak secara jelas terlihat (not overly observed).

Kalau variabel-variabel dibakukan (standardized), model analisis faktor dapat ditulis sebagai berikut :

$$
\begin{gathered}
X_{1}-\mu_{1}=l_{11} F_{1}+l_{12} F_{2}+\cdots+l_{1 n} F_{n} \\
+\varepsilon_{1} \\
X_{p}-\mu_{p}=l_{p 1} F_{1}+l_{p 2} F_{2}+\cdots+l_{p n} F_{n}+\varepsilon_{p}
\end{gathered}
$$

Atau dapat ditulis dalam notasi matrik sebagai berikut:

$\mathbf{X}_{\mathrm{pxl}}=\boldsymbol{\mu}_{(\mathrm{pxl})}+\mathbf{L}_{(\mathrm{pxm})} \mathbf{F}_{(\mathrm{mxl})}+\boldsymbol{\varepsilon}_{\mathrm{pxl}}$

$\left[\begin{array}{c}X_{1} \\ \ldots \\ X_{p}\end{array}\right]=\left[\begin{array}{c}\mu_{1} \\ \ldots \\ \mu_{p}\end{array}\right]+\left[\begin{array}{ccc}l_{11} & \ldots & l_{1 m} \\ \ldots & \ldots & \ldots \\ l_{p 1} & \ldots & l_{p m}\end{array}\right]\left[\begin{array}{c}F_{1} \\ \ldots \\ F_{m}\end{array}\right]+\left[\begin{array}{c}\varepsilon_{1} \\ \ldots \\ \varepsilon_{p}\end{array}\right]$

Dengan $(p x l) \quad(p x l) \quad(p x m)(m x l) \quad(p x l)$

$\mu_{1}=$ rata-rata variabel $i$

$\varepsilon_{\mathrm{i}}=$ factor spesifik ke-i

$\mathrm{F}_{\mathrm{j}}=$ common factor $\mathrm{ke}-\mathrm{j}$

$\mathrm{L}_{\mathrm{ij}}=$ loading dari variabel ke-I

pada factor ke-j

$\mathrm{m}$ = banyak factor

Faktor yang unik tidak berkorelasi dengan sesama faktor yang unik dan juga tidak berkorelasi dengan common factor. Common factor sendiri bisa dinyatakan sebagai kombinasi linear dari variabel-variabel yang terlihat/terobservasi (the observed variables) hasil penelitian lapangan.

$$
\begin{aligned}
& \quad \mathrm{F}_{\mathrm{i}}=\mathrm{W}_{\mathrm{i} 1} \mathrm{X}_{1}+\mathrm{W}_{\mathrm{i} 2} \mathrm{X}_{2}+\mathrm{W}_{\mathrm{i} 3} \mathrm{X}_{3} \\
& +\ldots+\mathrm{W}_{\mathrm{ik}} \mathrm{X}_{\mathrm{k}} \\
& i=1,2,3, \ldots, p \text { dan } k=1,2,3, \ldots, p \\
& \text { dengan: }
\end{aligned}
$$

$F i=$ Perkiraan faktor ke-i (didasarkan pada nilai variabel $X$ dengan koefisiennya Wi )

$W i=$ bobot atau koefisien nilai faktor ke-i 
$k=$ banyaknya variabel

Dimungkinkan untuk memilih timbangan (weight) atau koefisien nilai faktor (factor score coefficient) sehingga faktor yang pertama menjelaskan sebagian besar porsi seluruh varian atau menyerap sebagian besar varian seluruh variabel. Kemudian set timbangan kedua dapat dipilih, sehingga faktor yang kedua menyerap sebagian besar sisa varian, setelah diambil faktor pertama, dengan syarat bahwa faktor yang kedua tidak berkorelasi (orthogonal) dengan faktor pertama. Prinsip yang sama dapat dipergunakan untuk memilih faktor selanjutnya, sebagai faktor tambahan, yaitu faktor ketiga. Jadi, faktor bisa diperkirakan/diestimasi sehingga nilai faktor yang satu tidak berkorelasi dengan faktor lainnya. Faktor yang diperoleh merupakan variabel baru yang tidak berkorelasi antara satu faktor dengan faktor lainnya, artinya tidak terjadi multi collinearity. Banyaknya faktor lebih sedikit dari banyaknya variabel asli yang dianalisis faktor, sebab analisis faktor memang mereduksi jumlah variabel yang banyak menjadi variabel baru yang jumlahnya lebih sedikit.

Bagian dari varian variabel ke-i dari $m$ common faktor disebut komunalitas ke $-i$ yang merupakan jumlah kuadrat dari loading variabel ke - $i$ pada $m$ common faktor (Johnson \&Wichern, 2002), dengan rumus :

$$
\mathrm{h}^{2}=\square \mathrm{ii}^{2}+\square \mathrm{i}^{2}+\ldots+\square \mathrm{im}^{2}
$$

Hubungan antara varians variabel asal dengan, varians faktor dan varians error adalah sebagai berikut :
$\operatorname{var}(\mathbf{X} \mathbf{i})=$ varians yang dijelaskan oleh faktor untuk variabel asal ke-i + var(error)

variance

$=$ communality + specific

$=h_{i}^{2}+\varphi_{i}$

$=\left(\square_{11}{ }^{2}+\square_{12}^{2}+\ldots+\square \mathrm{m}\right)+\varphi_{i}$

Besarnya bobot ij dapat diduga

dengan menggunakan metode komponen utama ataupun kemungkinan maksimum (maximum likelihood). Metode komponen utama terbagi menjadi dua metode yaitu noniteratif dan iteratif. Nilai dugaan cij yang diperoleh dengan metode non-iteratif adalah : $\lambda$

$$
\square_{\mathrm{ij}} l_{i j}=\frac{a_{i j} \sqrt{\lambda_{j}}}{s_{x i}} \text { atau } l_{i j}=a_{i j} \sqrt{\lambda_{j}}
$$

untuk variabel asal yang dibakukan

dan

$\mathrm{I}_{\text {ij }}$ adalah bobot (loading) dari variabel asal ke-i pada faktor ke-j ij $\square$

$a_{i j}$ adalah koefisien variabel asal ke-i untuk komponen utama ke-j jia

$\lambda_{\mathrm{ij}}$ adalah eigen value untuk komponen utama ke- $j j \lambda$

$S_{x i}$ adalah simpangan baku (standard of deviation) variabel asal ke-j.

Untuk kepentingan intepretasi, seringkali diperlukan untuk memberi nama masing-masing faktor sesuai dengan besar harga mutlak bobot . Diharapkan setiap variabel asal hanya dominan di salah satu faktor saja (Nilai harga mutlak bobot variabel asal mendekati 1 di salah satu faktor dan mendekati 0 untuk faktor lainnya). Harapan ini kadang-kadang tidak dapat dipenuhi, untuk mengatasi hal ini diperlukan rotasi dari matriks bobot $\mathbf{L}$. Beberapa macam teknik rotasi yang tersedia di program paket statistika adalah : varimax, quartimax, equamax, 
parsimax. Batas nilai quartimax $=0$, batas nilai varimax $=1$, nilai equamax $=m / 2$, nilai parsimax $=\frac{p(m-1)}{p+m-2}$

\section{STATISTIK UJI DALAM ANALISIS FAKTOR}

Statistik penting yang berkaitan dengan analisis faktor adalah :

a. Bartlett's of sphericity yaitu suatu uji statistik yang dipergunakan untuk menguji hipotesis bahwa variabel tidak saling berkorelasi (uncorrelated) dalam populasi. Dengan kata lain, matriks korelasi populasi merupakan matriks identitas (identity matrix), setiap variabel berkorelasi dengan dirinya sendiri secara sempurna dengan $(r=1)$ akan tetapi sama sekali tidak berkorelasi dengan lainnya $(r=0)$.

Uji Bartlett bertujuan untuk mengetahui apakah terdapat hubungan antar variabel dalam kasus multivariat. Jika variabel $X 1, X 2, \ldots, X p$ independent (bersifat saling bebas), maka matriks korelasi antar variabel sama dengan matriks identitas. Sehingga untuk menguji kebebasan antar variabel ini, uji Bartlett menyatakan hipotesis sebagai berikut:

Hipotesis: $\mathrm{HO}: \boldsymbol{\rho}=\mathrm{I}$

$\mathrm{H} 1: \boldsymbol{\rho} \neq \mathbf{I}$

Statistik Uji :

$$
\begin{aligned}
& \bar{r}_{k}=\frac{1}{p-1} \sum_{i=1}^{p} r_{i k}, \mathrm{k}=1,2, \ldots, \mathrm{p} \\
& \bar{r}=\frac{2}{p(p-1)} \sum \sum_{i<k} r_{i k} \\
& \hat{\gamma}=\frac{(P-1)^{2}\left[1-(1-\bar{r})^{2}\right]}{p-(p-2)(1-\bar{r})^{2}} \\
& \text { dengan : }
\end{aligned}
$$

$\bar{r}_{k}=$ rata-rata elemen diagonal pada kolom atau baris ke $k$ dari matrik $\mathrm{R}$ (matrik korelasi) $\mathrm{kr}$

$$
\bar{r}=\text { rata-rata keseluruhan dari }
$$

elemen diagonal.

Daerah penolakan HO jika :

$$
\begin{aligned}
T=\frac{(n-1)}{(1-\bar{r})^{2}}\left[\sum \sum_{i<k}\left(r_{i k}-\bar{r}\right)^{2}\right. \\
\left.-\hat{\gamma} \sum_{i=1}^{p}\left(\bar{r}_{k}-\bar{r}\right)^{2}\right] \\
>x_{(p+1)(p-2) / 2, \alpha}^{2}
\end{aligned}
$$

Jika $\mathrm{H}_{0}$ ditolak maka variabel-variabel saling berkorelasi hal ini berarti terdapat hubungan antar variabel. Dengan demikian analisis multivariat layak untuk digunakan terutama metode analisis komponen utama dan analisis faktor.

b. Correlation matrix adalah matrik segitiga bagian bawah menunjukkan korelasi sederhana $r$, antara semua pasangan variabel yang tercakup dalam analisis. Nilai atau angka pada diagonal utama yang semuanya sama yaitu 1 diabaikan.

Tabel 1. Matrik korelasi Untuk Jumlah Variabel $n=3$

\begin{tabular}{|l|l|l|l|}
\hline & $X_{1}$ & $X_{2}$ & $X_{3}$ \\
\hline$X_{1}$ & 1 & $r_{12}$ & $r_{13}$ \\
\hline$X_{2}$ & $r_{21}$ & 1 & $r_{23}$ \\
\hline$X_{3}$ & $r_{31}$ & $r_{32}$ & 1 \\
\hline
\end{tabular}

Tabel 2. Matrik korelasi Untuk Jumlah Variabel $n=4$

\begin{tabular}{|l|l|l|l|l|}
\hline & $X_{1}$ & $X_{2}$ & $X_{3}$ & $X_{4}$ \\
\hline$X_{1}$ & 1 & $r_{12}$ & $r_{13}$ & $r_{14}$ \\
\hline$X_{2}$ & $r_{21}$ & 1 & $r_{23}$ & $r_{24}$ \\
\hline$X_{3}$ & $r_{31}$ & $r_{32}$ & 1 & $r_{34}$ \\
\hline$X_{4}$ & $r_{41}$ & $r_{42}$ & $r_{43}$ & 1 \\
\hline
\end{tabular}

c. Communality adalah jumlah varian yang disumbangkan oleh suatu variabel dengan seluruh variabel 
Tabel 3. Analisis Diskriptif

\begin{tabular}{|c|c|c|}
\hline Variabel & $\begin{array}{l}\text { Rata-rata } \\
\text { (Ton) }\end{array}$ & Rata-rata 2017 (Ton) \\
\hline X1(padi) & 23.305 & 18.196 \\
\hline X2(jagung) & 6.440 & 3.694 \\
\hline X3 (kedelai) & 63,8 & 6,01 \\
\hline X4(umbi) & 6.439 & 182,2 \\
\hline X5(tnmpangan) & 38.380 & 22.079 \\
\hline X6(buah) & 4.172 & 1.023 \\
\hline X7(sayur) & 16.625 & 1.023 \\
\hline
\end{tabular}

(Sumber : Data diolah, 2017)

lainnya dalam analisis. Bisa juga disebut proporsi atau bagian varian yang dijelaskan oleh common factor atau besarnya sumbangan suatu faktor terhadap varian seluruh variabel.

d. Eigenvalue merupakan jumlah varian yang dijelaskan oleh setiap faktor dari matriks identitas. Persamaan nilai eigen dan vektor eigen adalah (Silaban, 1984 : 279):

$$
A x=\lambda
$$

Dimana :

$\mathbf{A}=$ Matriks yang akan kita cari nilai eigen dan vektor eigennya

$\mathbf{x}=$ Vektor eigen dalam bentuk matriks $\lambda \lambda=$ Nilai eigen dalam bentuk skalar Untuk mencari nilai eigen (nilai ) dari sebuah matriks A yang beruukuran $n \mathrm{x}$ $n$ maka kita lakukan langkah berikut: $\mathbf{A x}=\mathbf{\lambda} \mathbf{x}$. Agar kedua sisi berbentuk vektor, maka sisi kanan dikali dengan matriks identitas I, sehingga :

$$
\begin{gathered}
\mathbf{A x}=\lambda \mathbf{I} \mathbf{X} \\
\mathbf{A x}-\lambda \mathbf{I} \mathbf{x}=\mathbf{0} \\
(\mathbf{A}-\lambda \mathbf{I})=\mathbf{0} \text { sehingga } \operatorname{det}(\mathbf{A}-\lambda \mathbf{I})=\mathbf{0}
\end{gathered}
$$

e. Factor loadings adalah korelasi sederhana antara variabel dengan faktor. f. Faktor loading plot adalah suatu plot dari variabel asli dengan menggunakan faktor loadings sebagai koordinat.

\section{ANALISIS DATA DAN PEMBAHASAN}

Dari data hasil komoditas pangan tentang varibel padi, jagung, kedelai, umbi-umbian, tanaman pangan, buah-buahan dan sayur-sayuran yang berada dalam 18 (delapan belas) kecamatan yang berada di kabupaten Gresik pada tahun 2016 dan tahun 2017. Dari data tersebut dapat dilihat nilai ratarata masing-masing komoditas pangan yang dihasilkan kabupaten Gresik pada tahun 2016 dan 2017.

Dari data tersebut dapat dilihat bahwa untuk komoditas pertanian yang dihasilkan di kabupaten Gresik pada 18 kecamatan, bahwa jenis tanaman pangan yang dihasilkan lebih banyak yaitu sebesar 38.380 ton pada tahun 2016 dan 22.079 ton pada tahun 2017, kemudian tanaman padi yang dihasilkan pada tahun 206 sebesar 23.305 ton dan pada tahun 2017 sebesar 18.196 ton. Berarti diharapkan 
jenis tanaman tersebut dapat memenuhi kebutuhan di kabupaten Gresik.Sedangkan untuk kebutuhan pada komoditas pertanian di tahun 2016 penghasillannya lebih banyak dibandingkan pada tahun 2017 dilihat secara rata-rata penghasilan hasil tersebut.

Sedangkan pada hasil analisis faktor tetang data komoditas pangan di kabupaten Gresik pada tahun 2016 yaitu berupa tanaman padi (X1), tanaman jagung (X2), tanaman kedelai (X3), tanaman umbi (X4), jenis tanaman pangan (X5), tanaman buahbuahan (X6), tanaman sayur(X7). Hasil yang diperoleh dari analisis faktor tersebut adalah diperoleh sebanyak 2 (dua) faktor pengelompokan dan dengan melihat nilai common factor dengan hasil analisis dengan menggunakan sofware SPPS pada table 4.

faktor $\begin{array}{cl}\text { Pada hasil analisis tersebut } \\ 1 & \text { dapat menerangakan }\end{array}$

$\begin{array}{ccc}\text { keragaman } & \begin{array}{c}\text { sebesar } \\ \text { faktor }\end{array} & 22, \\ \text { sedangkan } & \% \text {, }\end{array}$ menerangkan nilai keragaman data sebesar 30,5 \%. Brarti faktor 2 lebih penting dibandigkan dengan faktor 1 karena nilai-nilai yang diterangkan lebih besar oleh faktor2. Sedangkan untuk varibel-varibel yang termasuk dalam faktor 1 diantaranya tanaman jagung(X2), tanaman umbi(x4), tanaman pangan $(X 5)$ dan tanaman buah-buahan(X6). Dan untuk variabel yang masuk dalam faktor 2 diantaranya yaitu tanaman padi(X1), tanaman kedelai(X3) dan tanaman sayur(X7). Tiap-tiap faktor yang sama mempunyai pengaruh yang sama terhadap masing-masing variabel atau masing-masing tanaman yang dihasilkan, sehingga untuk faktor 1 konsentrasi yang harus ditingkatkan adalah tanaman jagung, tanaman umbi, tanaman pangan dan tanamann buah-buahan yang harus sama-sama untuk di tingkatkan karena mempunyai

Tabel 4. Analisis Faktor Data Tahun 2016

\begin{tabular}{lll}
\hline Variabel & Faktor 1 & Faktor 2 \\
\hline X1(padi) & 0,213 & 0,849 \\
X2(jagung) & 0,968 & 0,083 \\
X3 (kedelai) & 0,070 & 0,640 \\
X4(umbi) & 0,968 & 0,083 \\
X4(tnmpangan) & 0,701 & 0,658 \\
X5(buah) & 0,723 & -0.061 \\
X6(sayur) & $-0,215$ & 0,743 \\
\hline
\end{tabular}

(Sumber : Data diolah, 2017)

Tabel 5. Analisis Faktor Data Tahun 2017

\begin{tabular}{lccc}
\hline Variabel & Faktor $\mathbf{1}$ & Faktor 2 & Faktor 3 \\
\hline X1(padi) & $-0,090$ & 0,978 & 0,036 \\
\hline X2(jagung) & 0,566 & 0,189 & 0,351 \\
\hline X3 (kedelai) & $-0,043$ & 0,241 & 0,857 \\
\hline X4(umbi) & $-0,130$ & $-0,059$ & 0,880 \\
\hline X4(tnmpangan) & 0,062 & 0,985 & 0,147 \\
\hline X5(buah) & 0,946 & $-0,086$ & $-0,196$ \\
\hline X6(sayur) & 0,946 & $-0,086$ & $-0,196$ \\
\hline
\end{tabular}


nilai penghasil yang sama. Sdangkan untuk faktor 2 yaitu tanaman padi, tanaman kedelai dan tanaman sayur merupakan tanaman utama yang sangat dibutuhkan oleh masyarakat Gresik, sehingga tanaman tersebut harus selalu meningkat nilai penghasilannya.

Sedangkan pada hasil analisis faktor tetang data komoditas pangan di kabupaten Gresik pada tahun 2017 dari tujuh faktor tampak pada table 5.

Dari hasil analisis faktor dengan menggunakan perhitungan sofware SPSS didapat hasil bahwa untuk data komoditas pangan pada tahun 2017 dikelompokkan menjadi 3 faktor utama diantaranyavariabelvariabel yang masuk dalam tiap-tiap faktor diantaranya faktor 1 yaitu tanaman jagung (X2), tanaman buahbuahan (X5) dan tanaman sayursayuran(X6). Sedangkan faktor 2 yaitu tanaman padi (X1) dan tanaman pangan (X4). Dan untuk yang masuk dalam faktor 3 diantaranya tanaman kedelai (X3) dan tanaman umbi (x4). Untuk tanaman jagung, buah-buahan dan sayur mempunyai kesamaan hasil panen yang didapat dari daerah Gresik tersebut. Sedangkan untuk tanaman padi dan tanaman pangan adalah merupakan tanaman pokok yang harus selalu ditingkan penghasil panennya.

\section{TINJAUAN PUSTAKA}

Hines, W \& Montgomery, D. (1990). Probabilita Dan Statistik Dalam IImu Rekayasa Dan Manajemen. Jakarta : Penerbit Universitas Indonesia.

Johnson, R.A. dan Wichern, D. W, (2002), Applied Multivariate Statistical Analysis, Pentice Hall Inc, New Jersey.
Dan yang terakhir pada tanamnan kedelai dan umbi mempunyai nilai pengasil panen yang sama.

Untuk nilai keragaman yang dapat diterangakan pada masingmasing faktor adalah untuk faktor 1 sebesar $36,12 \%$ nilai keragaman yang dapat diterangkan, untuk faktor 2 sebesar $28,84 \%$ nilai keragaman yang dapat diterangkan dan untuk faktor 3 sebesar $19,48 \%$ keragaman yang dapat diteangkan pada faktor 3 tersebut. Berarti faktor yang penting karena menerangkan nilai keragaman paling banyak yaitu faktor 1 . Sehingga nilai-nilai pangan yang dihasilkan oleh faktor 1 harus diperhatikan leh pemerintah daerah Gresik tersebut.

\section{KESIMPULAN}

Dari hasil analisis data diatas bahwa nilai rata-rata data yang paling banyak adalah tanaman panga, kemudian tanaman padi. Sedangkan pada analisis faktor untuk komoditas pangan pada tahun 2016 terbagi menjadi dua faktor dengan nilai keragaman yang sama pada tiap-tiap faktor. Sedangkan pada tahun 2017 analisis faktor yang dihasilkan terbentuk menjadi 3 faktor dengan keragaman yang sama pada tiap-tiap faktornya juga.

Rancer, A. C(1995) Methods of Multivariate Anlysis, John Weley \& sons, Neyw York.

Sudjana. (2002). Metode Statistika. Bandung: Penerbit Tarsito.

Walpole, Ronald E. (1990). Pengantar Statistika. Jakarta: PT. Gramedia Pustaka Utama. 